\title{
Evaluation of minimum ripening time of artisanal mountain cheese from Santa Catarina prior to selling
}

\section{Avaliação do período mínimo de maturação para comercialização do queijo artesanal serrano de Santa Catarina}

\author{
Karine Andrezza Dalmina ${ }^{1 *}$; Leandro Parussolo ${ }^{2}$; Ricardo Antonio Pilegi \\ Sfaciotte $^{2}$; Fernanda Danielle $\mathrm{Melo}^{2}$; André Thaler $\mathrm{Neto}^{3}$; Sandra Maria Ferraz ${ }^{3}$
}

\begin{abstract}
Highlights:
Nenhum período de maturação avaliado garantiu a inocuidade do produto final. As propriedades apresentaram heterogeneidade nos procedimentos higiênico-sanitários. L. monocytogenes foi isolada nos quatro períodos de maturação da mesma propriedade. A fonte principal de contaminação do QAS pode ser pela manipulação inadequada.
\end{abstract}

\begin{abstract}
Artisanal mountain cheese (queijo artesanal serrano; AMS) is produced from raw milk, which makes it a suitable medium for the multiplication of pathogenic microorganisms. The ripening process involves physical, chemical and microbiological factors unfavorable to pathogen development. For this reason, the Brazilian legislation requires a minimum ripening time of 60 days. However, according to Normative Instruction (NI) no 30, of August 7, 2013, and Decree no. 9.013, of March 29, 2017, this time can be reduced provided that scientific studies show that there is no alteration in the safety of the product. This study aimed to evaluate the microbiological quality of AMS in 19 cheese factories in the Serra Catarinense region, at 14, 21, 28 and 35 days of ripening, and to determine which period would meet the microbiological limits. A total of 76 samples of AMS, 19 samples of water and 19 samples of raw milk were studied. The microorganisms were investigated following Ordinance no. 146, of March 7, 1996. The investigation and count of coliforms at $30^{\circ} \mathrm{C}$, E. coli and coagulase-positive Staphylococcus followed protocols by Silva et al. (2010), using Petrifilm ${ }^{\mathrm{TM}}$. The investigation of Salmonella spp. followed Silva et al. (2010), whereas the investigation of Listeria monocytogenese and count of mesophilic aerobes followed NI no. 30, of June 26, 2018. Water potability was evaluated by the Most Probable Number (MPN) technique, in accordance with NI no. 30/2018 and Consolidation Ordinance no. 5, of September 28, 2017. Results were tested by Analysis of Variance and Linear Regression using the SAS statistical package with significance determined at $p<0.05$. No safe ripening period for sale could be determined. At 35 days of ripening, 14 farms still showed counts above the limit for the microorganisms described in the legislation. On one of the farms, the presence of L. monocytogenes was detected in the four evaluated periods, demonstrating that ripening was not efficient to eliminate the pathogen. The microbiological quality of the milk was not satisfactory, with $63.16 \%$ of the samples not conforming to the standards. As regards the potability of the water used in the cheese factories, $52.63 \%$ of the analyzed samples showed unsatisfactory results. The research revealed heterogeneity
\end{abstract}

${ }^{1}$ M.e em Ciência Animal, Universidade do Estado de Santa Catarina, UDESC, Lages, SC, Brasil. E-mail: karine_dalmina@ hotmail.com

2 Drs. em Ciência Animal, UDESC, Lages, SC, Brasil. E-mail: leandroparussolo@gmail.com; sfaciotti@hotmail.com; fernandamelovet@gmail.com

3 Profs. Drs., Curso de Graduação em Medicina Veterinária, UDESC, Lages, SC, Brasil. E-mail: andre.thaler@udesc.br; sandra. ferraz@udesc.br

* Author for correspondence 
in the hygienic-sanitary standards adopted by the cheese factories, indicating that there is a need for training in Good Agricultural Practices and Good Manufacturing Practices, support from institutions, periodic inspection and commitment of producers to standardize the process.

Key words: Innocuousness. Ripening. Pathogens. Raw milk.

\section{Resumo}

O queijo artesanal serrano (QAS) é produzido a partir de leite cru, tornando-se um meio propício para a multiplicação de micro-organismos patogênicos. O processo de maturação envolve fatores físicos, químicos e microbiológicos que desfavorecem o desenvolvimento de patógenos. Diante disso, a legislação exige um período mínimo de 60 dias de maturação, porém, de acordo com a IN no 30 , de 7 de agosto de 2013 e com o Decreto $n^{\circ}$ 9.013, de 29 de março de 2017, pode-se considerar a possibilidade de reduzir esse tempo, desde que estudos científicos comprovem que não há alteração da inocuidade do produto. O objetivo do trabalho foi avaliar a qualidade microbiológica de QAS, em 19 queijarias da Serra Catarinense, com 14, 21, 28 e 35 dias de maturação e verificar qual período atenderia aos limites microbiológicos. Foram objetos de estudo 76 amostras de QAS, 19 amostras de água e 19 amostras de leite cru. Os micro-organismos pesquisados seguiram a Portaria $\mathrm{n}^{\circ} 146$, de 07 de março de 1996. A pesquisa e quantificação de coliformes a $30^{\circ} \mathrm{C}$, E. coli e Staphylococcus coagulase-positiva, seguiram protocolos de Silva et al. (2010), utilizando Petrifilm ${ }^{\mathrm{TM}}$. A pesquisa de Salmonella spp. seguiu Silva et al. (2010) e a pesquisa de Listeria monocytogenese e a quantificação de aeróbios mesófilos seguiram a Instrução Normativa $\mathrm{n}^{\circ}$ 30, de 26 de junho de 2018. Para avaliação da potabilidade da água foi realizada a técnica do Número Mais Provável (NMP), seguindo a IN no 30/2018 e a Portaria de Consolidação ${ }^{\circ}$ 5, de 28 de setembro de 2017. Os resultados passaram por teste de Análise de Variância e Regressão Linear do pacote estatístico SAS com significância $(\mathrm{p}<0.05)$. Nesse estudo, não foi possível determinar um período de maturação seguro para comercialização. Aos 35 dias de maturação, 14 propriedades ainda apresentaram quantificações acima do limite para os micro-organismos descritos na legislação. Em uma das propriedades, foi detectada a presença de L. monocytogenes nos quatro períodos avaliados, demonstrando que a maturação não foi eficiente para eliminar o patógeno. A qualidade microbiológica do leite não foi satisfatória, sendo que $63,16 \%$ das amostras estavam fora dos padrões. Com relação à potabilidade da água das queijarias, $52,63 \%$ das amostras analisadas apresentaram resultados insatisfatórios. A pesquisa indicou heterogeneidade nos padrões higiênico-sanitários das queijarias, demonstrando que são necessárias capacitações em Boas Práticas Agropecuárias e Boas Práticas de Fabricação, apoio de instituições, fiscalização periódica e comprometimento dos produtores para padronização do processo.

Palavras-chave: Inocuidade. Leite cru. Maturação. Patógenos.

\section{Introduction}

Artisanal mountain cheese (queijo artesanal serrano; AMS) is produced by several rural families who seek a source of income through the activity (Córdova et al., 2013). The main characteristic of its production is the use of raw cow's milk (Córdova et al., 2011), i.e., the raw material does not undergo any heat treatment that can eliminate possible pathogens. Therefore, AMS can be considered an excellent culture medium, as it has high nutritional value for the multiplication of microorganisms (Germano \& Germano, 2010).
The ripening process is essential to ensure the safety of this product, as there is a reduction in moisture, a drop in $\mathrm{pH}$ and an increase in the sodium chloride concentration during this stage. These physico-chemical alterations disfavor the presence of undesirable bacteria and contribute to the permanence of lactic acid bacteria, which are responsible for the color, texture and flavor of the cheese (Sales, 2015). According to Decree no. 9,013, of March 29, 2017 (Decreto 9.013, 2017), in conjunction with Ordinance no. 146, of March 7, 1996 (Portaria n. 146, 1996), the ripening stage 
must be no less than 60 days and must be carried out at a temperature above $5{ }^{\circ} \mathrm{C}$.

However, because consumers prefer less mature pieces, the ripening time is seldom respected by producers, rendering the product irregular under the legislation (Córdova, Schlickmann, \& Pinto, 2014).

Considering these issues surrounding producers from all parts of Brazil, Normative Instruction no. 30, of August 7, 2013 (Instrução Normativa n. 30, 2013) and Decree no. 9,013/2017 allow the sale of artisanal cheeses made from raw milk with a ripening period of less than 60 days provided that product safety is confirmed by conclusive technicalscientific studies.

Some regions have already obtained this validation and reduced ripening time, such as the state of Minas Gerais with Canastra cheese, which is now legally marketed after 21 days of ripening "UFMG Study guarantees: 14 days of curing is sufficient for the cheeses in Araxá" (Passil, 2015).

The aim of this study was to examine the microbiological quality of AMS in four ripening periods less than 60 days at cheese factories under the process of legalization, as well as determine which period meets the safe microbiological standard for sale.

\section{Materials and Methods}

\section{Sampling}

The study was conducted in 19 cheese factories located on farms in 10 municipalities in the mountainous region of the state of Santa Catarina, Brazil (Figure 1).

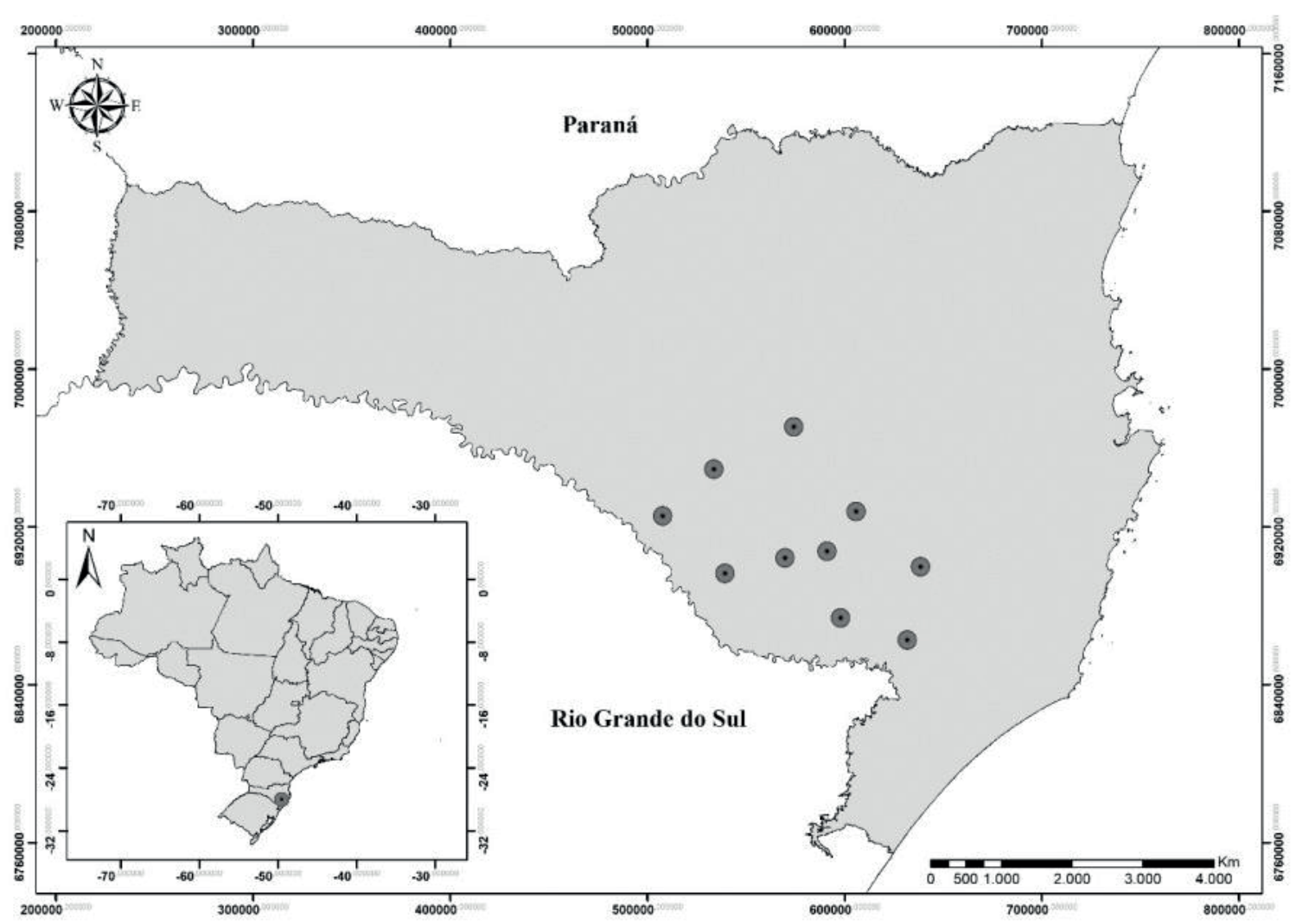

Figure 1. Location of the cheese factories that participated in the study, in Serra Catarinense. 
The cheese factories were adjusting to the legislation requirements to legalize their production. During the collection period, only three factories already possessed municipal inspection certification. The physical structure of the cheese factories complied with the legislation (Decreto $\mathrm{n}$. $1.238,2017)$; however, on some farms, the milking parlor and the animal waiting room were not in conformity to the decree and were thus not suitable for obtaining the raw material.

Collections were carried out after training the producers of artisanal mountain cheese (AMS), addressing mainly the care related to hygiene in obtaining the raw material and producing the AMS and relating it to the main contaminating microorganisms described in the legislation. This research evaluated samples of AMS, water and raw milk used on the day the cheese pieces were manufactured.

Four samples of AMS were collected from each farm, from the same mass, at different ripening times (14, 21, 28 and 35 days), totaling 76 samples. The pieces were identified and remained in the ripening rooms until the respective collection date. The ripening process took place in ambient humidity and temperature conditions. For uniformity purposes, it was established that the cheeses would weigh between 900 and $1,100 \mathrm{~g}$ on the day of manufacture.

Water samples were collected from the production room of the cheese factories, in sterile bags, each containing $100 \mathrm{~mL}$. Milk samples were collected in sterile flasks containing $100 \mathrm{~mL}$ directly from the AMS production tank from each farm, after homogenization.

All samples were properly packed in cooler boxes at refrigeration temperature $\left(2-8{ }^{\circ} \mathrm{C}\right)$, and sent to the Animal Microbiological Diagnostic Center (CEDIMA) of Santa Catarina State University (UDESC).

\section{Bacteriological analysis}

The following analyses were performed on milk and cheese: Listeria monocytogenes and Salmonella spp. investigation; and count of coliforms at $30{ }^{\circ} \mathrm{C}$, Escherichia coli, coagulase-positive Staphylococcus and mesophilic aerobes (Standard Plate Count SPC). To evaluate the potability of the water in the establishments, coliforms at $30{ }^{\circ} \mathrm{C}$ and Escherichia coli were investigated.

For microbiological analysis of AMS, the upper rind was initially removed aseptically to avoid any surface contamination. The counts of coliforms at 30 ${ }^{\circ} \mathrm{C}$, E. coli and coagulase-positive Staphylococcus were performed according to protocols described by Silva et al. (2010) using the Petrifilm ${ }^{\mathrm{TM}}$ system (method validated by the Association of Analytical Communities - AOAC) no. 991.14 for coliforms at $30{ }^{\circ} \mathrm{C}$ and E. coli and no. 2003.07 for coagulasepositive Staphylococcus. The final result was expressed in CFU/g (cheese) and CFU/mL (milk).

The isolation protocol for Salmonella spp. was carried out in accordance with ISO 6579 (2007), described by Silva et al. (2010). The investigation of $L$. monocytogenes was performed in accordance with Normative Instruction no. 30 (Instrução Normativa n. 30, 2018). Suspected isolates underwent biochemical tests for confirmation (Silva et al., 2010).

Analyses for the quantification of mesophilic aerobes in cheese and milk followed Normative Instruction no. 30 (Instrução Normativa n. 30, 2018), based on the parameters of Normative Instruction no. 76 (Instrução Normativa n. 76, 2018), which establishes a maximum limit of $300,000 \mathrm{CFU} / \mathrm{mL}$ in cooled raw milk.

To evaluate the microbiological quality of water, the most probable number (MPN) quantitative technique was used, following Normative Instruction no. 30 (Instrução Normativa n. 30, 2018). 
The results found in this study were compared with the reference values according to Ordinance no. 146 (Portaria n. 146, 1996). As a parameter, in its technical regulation of cheese identity and quality, Ordinance no. 146/1996 includes different reference values according to the moisture content of the cheese. In this case, the AMS samples fit the medium-moisture class (between 36\% and $45.9 \%$ ), as described in a study that examined AMS samples in the same ripening periods as this study (Pereira, Freire, Escatolin, Silva \& Caon, 2018). In medium-moisture cheeses, the maximum allowed count for coliforms at $30{ }^{\circ} \mathrm{C}$ is $5,000 \mathrm{CFU}$ g; for Escherichia coli, $500 \mathrm{CFU} / \mathrm{g}$; and for coagulasepositive Staphylococcus, 1,000 CFU/g. Water potability results were compared with Annex XX of Consolidation Ordinance no. 5, of September 28, 2017 (Portaria de Consolidação n. 5, 2017).

\section{Statistical analysis}

Results were subjected to analysis of variance and linear regression using the SAS statistical package, with significance declared at $p<0.05$.

\section{Results and Discussion}

Results pertaining to the AMS samples used in the evaluation of isolation frequency and the influence of ripening periods on the count of microorganisms described in the legislation are shown in Table 1.

Table 1

Isolation frequency and influence of ripening period on the mean of count of coliforms at $30^{\circ} \mathrm{C}$, Escherichia coli and coagulase-positive Staphylococcus

\begin{tabular}{ccccccc}
\hline \multirow{2}{*}{ Ripening time } & \multicolumn{5}{c}{ Samples with bacterial growth/ Mean (CFU/g) } \\
\cline { 2 - 7 } & $\begin{array}{c}\text { Coliforms at } \\
\mathbf{3 0}^{\circ} \mathbf{C}\end{array}$ & Mean & $\begin{array}{c}\text { Escherichia } \\
\text { coli }\end{array}$ & Mean & $\begin{array}{c}\text { Coag.-positive } \\
\text { Staphylococcus }\end{array}$ & Mean \\
\hline $\mathbf{1 4}$ days & $19 / 19$ & $1.625 \times 10^{6 \mathrm{a}}$ & $13 / 19$ & $3.017 \times 10^{5 \mathrm{a}}$ & $13 / 19$ & $9.958 \times 10^{4 \mathrm{a}}$ \\
$\mathbf{2 1}$ days & $17 / 18$ & $1.073 \times 10^{6 \mathrm{~b}}$ & $11 / 18$ & $2.091 \times 10^{5 \mathrm{a}}$ & $15 / 19$ & $1.018 \times 10^{5 \mathrm{a}}$ \\
$\mathbf{2 8}$ days & $19 / 19$ & $1.159 \times 10^{6 \mathrm{~b}}$ & $14 / 19$ & $4.104 \times 10^{5 \mathrm{a}}$ & $11 / 19$ & $3.358 \times 10^{4 \mathrm{~b}}$ \\
$\mathbf{3 5}$ days & $19 / 19$ & $3.813 \times 10^{5 \mathrm{~b}}$ & $16 / 19$ & $2.441 \times 10^{5 \mathrm{a}}$ & $5 / 19$ & $2.633 \times 10^{4 \mathrm{c}}$ \\
Total & $74 / 75$ & & $54 / 75$ & & $44 / 76$ & \\
\hline
\end{tabular}

Note. ${ }^{\mathrm{a}, \mathrm{b}, \mathrm{c}}$ Different letters in the same column indicate statistical difference $(\mathrm{p}<0.05)$.

The group of coliforms at $30{ }^{\circ} \mathrm{C}$ decreased in number after 21 days of ripening $(p<0.05)$, whereas no statistical difference was detected for E. coli between the evaluated periods $(\mathrm{p}>0.05)$. By contrast, the count of coagulase-positive Staphylococcus decreased significantly after 28 days of ripening $(\mathrm{p}<0.05)$.

Besides the high initial contamination of milk, the higher count of the group of coliforms compared with coagulase-positive Staphylococcus may also be related to the competition between lactic acid and coliform bacteria that occurs when the $\mathrm{pH}$ is still high and the temperature is adequate, in the first periods of ripening. These initial factors favor the multiplication of coliforms, which consequently inhibit the multiplication of coagulase-positive Staphylococcus (Dias, Ferreira, Carvalho, \& Soares, 2016). Throughout the ripening stage, the trend in this process is a progressive reduction of pathogens due to the processes that take place, such as acidification of the medium, reduction of 
water activity $\left(\mathrm{a}_{\mathrm{w}}\right)$ and competition with lactic acid bacteria (Ordóñez, 2005).

Nonetheless, if the hygienic-sanitary conditions during the manufacturing process are unsatisfactory, ripening alone does not ensure the safety of the final product. This observation was made in the study of Borges (2015), who evaluated Minas-type cheeses made with raw milk and reported that the values found in all periods (for most parameters) exceeded the acceptable legislation limits even after 60 days of ripening (with a moisture content of $9 \%$ ), demonstrating that this period was not sufficient to ensure a safe product for consumption.

Melo et al. (2013) evaluated AMS samples at 15, 30,45 at 60 days of ripening and observed a reduction in the coliform population at $30^{\circ} \mathrm{C}$ and in E. coli at 30 and 45 days of ripening, respectively. There was a reduction in the population of coagulase-positive Staphylococcus at 15 and 45 days of ripening, which was followed by an increase in the count of this microorganism.

Coagulase-positive Staphylococcus is considered a resistant agent that can grow in a $\mathrm{pH}$ range of 4.2 to 9.3 , survives a minimum water activity of up to $0.85\left(\mathrm{a}_{\mathrm{w}}\right)$ and tolerates $\mathrm{NaCl}$ concentrations of up to $25 \%$ (Silva et al., 2010). However, unlike other experiments in which their count increased over the days, in the present study there was a significant reduction in the number of these microorganisms. This phenomenon may be associated with the high levels of coliforms at $30{ }^{\circ} \mathrm{C}$ and $E$. coli found at 35 days of ripening. According to Vernozy-Rozand, Mazuy-Cruchaudet, Bravai and Richard (2004), at very high concentrations of competing bacteria, coagulase-positive Staphylococcus has a lower multiplication rate, demonstrating its sensitivity to competition with other microorganisms.

In this study, no Salmonella spp. were isolated in the analyzed AMS samples. Similarly, in other studies with cheeses made from raw milk, no strains of Salmonella sp. were isolated in any of the evaluated ripening periods (Andrade, Bezerra, Andrade,
Nascimento, \& Pereira, 2016; Borges, 2015; Melo et al., 2013; Nespolo, Taffarel, \& Brandelli, 2009; Pontarolo, 2014). The non-detection of Salmonella spp. in milk might have been simply because this pathogen was not present, or even due to its limited ability to compete with Staphylococcus spp. and coliforms (Brant, Fonseca, \& Silva, 2007), which were detected at high percentages in this study, representing a potential risk for the presence of enteropathogens such as Salmonella spp.

On one farm, Listeria monocytogenes strains were isolated in the four ripening periods (5.26\%), rendering the product unfit for consumption and demonstrating that the evaluated ripening periods did not contribute to the elimination of this microorganism, as seen for $E$. coli.

In studies carried out in the same region, Melo et al. (2013) identified L. monocytogenes in three samples of AMS, isolated at 30 and 45 days of ripening, whereas Pontarolo (2014) isolated this agent in a sample of AMS at 14 days and in two samples at 28 days of ripening.

Unlike the aforementioned studies, the presence of L. monocytogenes at the four ripening times found in the current experiment may be associated with the ability of the agent to tolerate higher salt concentrations over the ripening time (Sales, 2015).

This microorganism is of concern for the food industry due to its resistance to disinfectants and ability to form biofilm, which, when present, indicates poor hygiene and can contaminate any food that comes into contact with the surface (Klančnik, Toplak, Kovač, \& Jeršek, 2015).

According to the microbiological limits described in Ordinance No. 146 (Portaria n. 146, 1996), the percentages of AMS samples unfit for consumption are shown in Table 2.

When each farm was analyzed individually in relation to the ripening periods, it was observed that at 14 days, two (2/19) of them presented cheeses suitable for consumption. At 21 days, only one 
(1/19) farm obtained satisfactory results and, at 28 and 35 days, five (5/19) farms obtained products fit for consumption.

Regarding the percentage of non-conformity, of the 76 analyzed samples of AMS, the group of coliforms at $30{ }^{\circ} \mathrm{C}$ was above the allowed limits in $67.10 \%$ of the samples. For E. coli, the percentage of non-conforming samples reached $48.68 \%$, and for coagulase-positive Staphylococcus, a nonconformity rate of $32.89 \%$ was found.

Table 2

Number of samples outside microbiological standards for coliforms at $30^{\circ} \mathrm{C}$ (above $5 \times 103 \mathrm{CFU} / \mathrm{g}$ ), Escherichia coli (above $5 \times 102 \mathrm{CFU} / \mathrm{g}$ ) and coagulase-positive Staphylococcus (above $103 \mathrm{CFU} / \mathrm{g}$ ) and mean counts

\begin{tabular}{cccccccc}
\hline $\begin{array}{c}\text { Ripening } \\
\text { period }\end{array}$ & $\begin{array}{c}\text { Coliforms at } \\
\mathbf{3 0}^{\circ} \mathbf{C}\end{array}$ & Mean & $\begin{array}{c}\text { Non-conforming samples/Mean (CFU/g) } \\
\text { coli }\end{array}$ & Mean & $\begin{array}{c}\text { Coag.-positive } \\
\text { Staphylococcus }\end{array}$ & Mean \\
\hline $\mathbf{1 4}$ days & $15 / 19$ & $2.058 \times 10^{6}$ & $10 / 19$ & $5.733 \times 10^{5}$ & $10 / 19$ & $1.891 \times 10^{5}$ \\
$\mathbf{2 1}$ days & $13 / 19$ & $2.378 \times 10^{6}$ & $10 / 19$ & $3.993 \times 10^{5}$ & $9 / 19$ & $1.933 \times 10^{5}$ \\
$\mathbf{2 8}$ days & $12 / 19$ & $1.834 \times 10^{6}$ & $8 / 19$ & $9.746 \times 10^{5}$ & $4 / 19$ & $1.590 \times 10^{5}$ \\
$\mathbf{3 5}$ days & $11 / 19$ & $6.578 \times 10^{5}$ & $9 / 19$ & $5.153 \times 10^{5}$ & $2 / 19$ & $2.500 \times 10^{5}$ \\
Total & $51 / 76$ & & $37 / 76$ & & $25 / 76$ & \\
\hline
\end{tabular}

In the study led by Melo et al. (2013) with AMS samples, the author obtained values lower than or similar to the present findings. For coliforms at 30 ${ }^{\circ} \mathrm{C}, 34.26 \%$ of the samples were above the legal limit; for E. coli, $36.11 \%$. For coagulase-positive Staphylococcus, the percentage of non-conformity was $33.33 \%$, a result similar to that found in this study.

It is important to highlight that the results found by Melo et al. (2013) were obtained in an entirely different production reality compared with the current case, as the samples were acquired from rural producers who did not have any training in Good Manufacturing Practices (GMP) and did not possess adequate physical structure for the production of AMS.

Conversely, in the current survey, the 19 farms that participated in the collections already had well-structured cheese factories, most of which were equipped with a waiting room for animals and a milking parlor suitable for obtaining the raw material. In addition, the producers received brief training in GMP prior to the collections.
The population of mesophilic aerobes in the AMS samples decreased after 21 days of ripening $(p<0.05)$, on all farms. However, even with this decrease, at 35 days, the count of these microorganisms was still high, ranging from $1.1 \times$ 106 to $3.3 \times 109 \mathrm{CFU} / \mathrm{g}$.

Andrade et al. (2016) also found a high count of mesophilic aerobes in rennet cheese, which increased from $3.5 \times 106$ (day zero) to $2 \times 108$ CFU/g (42 days). Borges (2015), in turn, obtained a very high value $(1.5 \times 109 \mathrm{CFU} / \mathrm{g})$ on the first day of ripening of Minas cheese produced with raw milk. The largest population was found at 20 days of ripening $(3.6 \times 1011 \mathrm{CFU} / \mathrm{g})$ and, in the last evaluated period ( 60 days), a population of $2.1 \times$ $104 \mathrm{CFU} / \mathrm{g}$ was detected (Borges, 2015).

High counts of mesophilic aerobes in cheese indicate hygienic-sanitary failures, where the product may have been made from highly contaminated raw material; unsatisfactory hygiene in handling and during the production process; or even storage in inadequate time and temperature conditions (Wolupeck, Raska, Rossa, Biasi, \& Macedo, 2012). 
Only seven farms (36.84\%) had satisfactory results in terms of the microbiological quality of raw milk (SPC). The values found ranged from 3 $\times 102 \mathrm{CFU} / \mathrm{mL}$ to $1.9 \times 105 \mathrm{CFU} / \mathrm{mL}$. On the 12 farms that were in disagreement with the legislation (values above $3 \times 105 \mathrm{CFU} / \mathrm{mL}$ ), results ranged from $5.1 \times 105 \mathrm{CFU} / \mathrm{mL}$ to $7.5 \times 107 \mathrm{CFU} / \mathrm{mL}$.

Medeiros (2017) evaluated the quality of milk used in informal artisanal-cheese factories and the results found for SPC exceeded the maximum limits described in the legislation in all participating factories. Because the main characteristic of the production of AMS is the use of raw milk, strict hygienic-sanitary control must be adopted in obtaining the raw material; otherwise, a high count of pathogenic and deteriorating bacteria may be present which consequently will be transferred to the cheese (Pereira et al., 2014).

Contamination initiating after milking may be due to failures associated with the cleaning and hygiene of equipment and utensils that come into contact with milk, poor hygiene of the teats before milking and also the presence of mastitis (Taffarel, Costa, Oliveira, Braga, \& Zonin, 2013).

The percentage of non-conformity for SPC in the milk samples found in this study is high (63.16\%) when compared with previous studies with AMS. Pontarolo (2014) found $48.39 \%$ of non-conformity with regard to SPC and stated that there is variability in the sanitary management of farms, e.g., lack of adequate structures, deficient milking hygiene and ineffective control of mastitis. Likewise, the result found in this study may be a consequence of all these factors pertaining to milking hygiene and product storage.

The results for the count of mesophilic aerobes suggest that the initial contamination of milk (SPC) had no significant effect on the contamination of the cheeses analyzed at 14 days of ripening $(p>0.05)$.

In this study, $89.47 \%(17 / 19)$ of the milk samples had coliforms at $30{ }^{\circ} \mathrm{C} ; 10.52 \%(2 / 19)$ had E. coli; and 100\% (19/19) had coagulasepositive Staphylococcus. The observed counts of coliforms at $30{ }^{\circ} \mathrm{C}$, E. coli and coagulase-positive Staphylococcus in milk were compared with the values found in cheeses at 14 days of ripening. The results revealed that the contamination of milk by these microorganisms had no significant impact on the contamination found in the cheeses at 14 days ( $>0.05$ ), which reinforces the hypothesis that the contamination of the cheeses was likely the result of inadequate handling and environmental conditions.

In the work developed by Pontarolo (2014), unlike this study, the count of coagulase-positive Staphylococcus in milk had a significant effect $(p<0.05)$ on the quality of cheese at 14 days, whereas coliforms at $30{ }^{\circ} \mathrm{C}$ and E. coli exhibited no correlation. In milk analyses, Sequetto et al. (2017) found $80 \%$ of samples contaminated by coliforms at $30{ }^{\circ} \mathrm{C}$ and $40 \%$ by E. coli.

In the present study, no Salmonella spp. or $L$. monocytogenes were isolated in any milk sample. Nero (2005) evaluated 210 samples of raw milk from four different regions of Brazil and also did not detect the presence of $L$. monocytogenese or Salmonela spp., but reported high counts of mesophilic aerobes, coliforms at $30^{\circ} \mathrm{C}$ and E. coli.

In the analyses of water potability, of the 19 samples analyzed, 10 (52.63\%) showed coliforms at $30{ }^{\circ} \mathrm{C}$, disagreeing with the legislation that recommends the absence of these microorganisms (Portaria de Consolidação n. 5, 2017). By contrast, there was no presence of $E$. coli in any of the samples. Although $52.63 \%$ of the samples do not meet the potability standards, there was no significant influence of water contamination on the cheeses at 14 days of ripening.

In a similar study, Pontarolo (2014) found a total of $41.94 \%$ non-conforming water samples for coliforms at $30{ }^{\circ} \mathrm{C}$ and $3.23 \%$ non-conforming samples for E. coli. However, the microbiological quality of the water on the farms also had no 
significant influence on contamination by coliforms or E. coli in the cheeses at 14 days of ripening.

One of the factors that can contribute to alterations in water quality is rainfall, which causes runoff and may lead to contamination of the soil/ environment near the spring or source of water used (Geldreich, 1998). Therefore, attention should be directed towards the water potability conditions of farms, since contaminated water can cause the transfer of bacterial load to milk and its derivatives, which can lead to a public health problem (Picinin, 2010).

\section{Conclusion}

This study has demonstrated that none of the evaluated ripening periods (14, 21, 28 and 35 days) was effective in ensuring the safety of the final product. The results found in the cheese factories reveal heterogeneity in the production processes, especially those involving hygiene in obtaining the raw milk and in handling the product, which directly reflected in the hygienic-sanitary quality of artisanal mountain cheese. On this basis, the minimum ripening time of 60 days provided for by the legislation should be maintained and the procedures carried out in cheese factories should be standardized, with frequent training courses, inspection by the responsible bodies and commitment of producers regarding the required standards.

\section{Acknowledgments}

Thanks are due to the Agricultural Research and Rural Extension Company of Santa Catarina (EPAGRI), its technicians and extension workers for their assistance during the research; to the producers, for providing the samples; to CAPES, for the Master's fellowship grant of the first author; and to FAPESC, for the financial assistance for the development of this study.

\section{References}

Andrade, V. O., Bezerra, L. M. A., Andrade, J. O., Nascimento, M. M., \& Pereira, E. M. (2016). Qualidade microbiológica de queijo coalho. Anais do Congresso Internacional de Ciências Agrárias, Vitória de Santo Antão, PE, Brasil, 1. Recuperado de https://cointerpdvagro.com.br/ wp-content/uploads/ 2016/12/QUALIDADEMICROBIOL\%C3\%93GICA-DE-QUEIJO-DECOALHO.pdf

Borges, L. C. (2015). Efeitos do processo de maturação sobre a microbiota autóctone de queijo produzido com leite cru. Trabalho de conclusão de curso, Universidade de Brasília, Brasília, DF, Brasil. Recuperado de http://bdm.unb.br/ handle/10483/13532

Brant, L. M. F., Fonseca, L. M., \& Silva, M. C. C. (2007). Avaliação da qualidade microbiológica do queijo de minas artesanal do Serro - MG. Arquivo Brasileiro de Medicina Veterinária e Zootecnia, 59(6), 1570574.

Córdova, U. de A., Schlickmann, A. F. M. B. F., Pucci, A. A., Schlichting, A. P., Couto, C. A. L., Nunes, I. R.,... Pereira, S. Neto. (2013). Queijo Artesanal Serrano: história, cultura e geração de renda nos campos de altitude no sul do Brasil. Florianópolis, $\mathrm{SC}$ : EPAGRI/GMC.

Córdova, U. A., Pucci, A. A., Schlichting, A. P., Schlickmann, A. F. M. B. F., Santos, A. P. S., Mota, D. M. L., Pereira Neto, S. (2011). O queijo artesanal serrano nos campos do Planalto das Araucárias catarinense. Florianópolis, SC: EPAGRI.

Córdova, U. A., Schlickmann, A. F. M. B. F., \& Pinto, C. E. (2014). A contribuição do Queijo Artesanal Serrano para o desenvolvimento regional e preservação dos campos de altitude do sul do Brasil. Revista Eletrônica do Programa de Mestrado em Desenvolvimento Regional da Universidade do Contestado, 4(2),103-114. doi: 10.24302/drd. v4i2.727

Decreto $n$. 1.238, de 19 de julho de 2017. Regulamenta a Lei $\mathrm{n}^{\circ} 17.003$, de 2016, que dispões sobre a produção e comercialização do queijo artesanal serrano, no Estado de Santa Catarina. Recuperado de http://www.cidasc.sc.gov.br/inspecao/files/2012/08/ Decreto-1238-2017-PDF-SCC-6258-2017.pdf

Decreto n. 9.013, de 29 de março de 2017. Regulamenta a Lei $\mathrm{n}^{\circ} 1.283$, de 18 de dezembro de 1950 , e a Lei $\mathrm{n}^{\mathrm{o}} 7.889$, de 23 de novembro de 1989 , que dispõem sobre a inspeção industrial e sanitária de produtos de 
origem animal. Recuperado de www.planalto.gov. br/ccivil_03/_Ato2015-2018/2017/Decreto/ D9013. htm

Dias, B. F., Ferreira, S. M., Carvalho, V. S., \& Soares, D. S. B. (2016). Qualidade microbiológica e físicoquímica de queijo minas frescal artesanal e industrial. Revista de Agricultura Neotropical, 3(3), 57-64. doi: 10.32404/rean.v3i3.1211

Geldreich, E. E. (1998). The bacteriology of water. In L. Colier, A. Balows, \& M. Sussman (Eds.), Microbiology and microbial infections (9a ed.). London: Arnold.

Germano, P. M. L., \& Germano, M. I. S. (2010). Higiene e vigilância sanitária de alimentos. Barueri, SP: Manole.

Instrução Normativa n. 30, de 26 de junho de 2018. Estabelece como oficiais os métodos constantes do Manual de Métodos Oficiais para Análise de Alimentos de Origem Animal, disponível no sítio eletrônico do MAPA, para realização de ensaios em amostras de produtos de origem animal, oriundas dos programas e controles oficiais do MAPA. Recuperado dehttp://www.in.gov.br/materia/-/asset publisher/Kujrw0TZC2Mb/content/id/29896222/ do1-2018-07-13-instrucao-normativa-n-30-de-26de-junho-de-2018-29896212

Instrução Normativa n. 30, de 7 de agosto de 2013. Estabelece critérios para elaboração de queijos artesanais. Recuperado de www.in.gov.br/materia/-/ asset_publisher/Kujrw0TZC2Mb/content/id/ 30808894/do1-2013-08-08-instrucao-normativa-n30-de-7-de-agosto-de-2013-30808890

Instrução Normativa n. 76, de 26 de novembro de 2018. Ficam aprovados os Regulamentos Técnicos que fixam a identidade e as características de qualidade que devem apresentar o leite cru refrigerado, o leite pasteurizado e o leite pasteurizado tipo A. Recuperado de https://wp.ufpel.edu.br/inspleite/ files/ 2019/04/INSTRUÇÃO-NORMATIVA-Nº-76DE-26-DE-NOVEMBRO-DE-2018-Diário-Oficialda-União-Imprensa-Nacional.pdf

Klančnik, A., Toplak, N., Kovač, M., \& Jeršek, H. M. B. (2015). Quantification of Listeria monocytogenes cells with digital PCR and their biofilm cells with real-time PCR. Journal of Microbiological Methods, 118, 37-41. doi: 10.1016/j.mimet.2015.08.012

Medeiros, N. C. (2017). Qualidade do leite utilizado em queijarias artesanais no Rio Grande do Norte. Dissertação de mestrado, Universidade Federal Rural do Semi-Árido, Mossoró, RN, Brasil.
Melo, F. D., Dalmina, K. A., Pereira, M. N., Ramella, M. V., Thaler, A Neto, Vaz, E. K., \& Ferraz, S. M. (2013). Avaliação da inocuidade e qualidade microbiológica do queijo artesanal serrano e sua relação com as variáveis físico químicas e o período de maturação. Acta Scientiae Veterinariae, 41(1152), 1-7.

Nero, L. A. (2005). Listeria monocytogenes e Salmonella spp. em leite cru produzido em quatro regiões no Brasil, fatores que interferem sua detecção. Tese de doutorado, Universidade de São Paulo, São Paulo, SP, Brasil. Recuperado de http://www.teses.usp.br/ teses/disponiveis/9/9131/tde-09052005-174614/ptbr.php

Nespolo, C. R., Taffarel, J. A. S., \& Brandelli, A. (2009). Parâmetros microbiológicos e físico-químicos durante a produção e maturação do queijo Fascal. Acta Scientiae Veterinariae, 37(4), 323-328. doi: 10.22456/1679-9216.16391

Ordóñez, J.A. (2005). Tecnologia de alimentos: alimentos de origem animal. Porto Alegre, RS: Artmed.

Passil, L. (2015). Pesquisa da UFMG garante: 14 dias de cura é suficiente para os queijos em Araxá. Recuperado de http://www.sertaobras.org. br/2015/11/27/pesquisada-da-ufmg-garante-14-diase-suficiente- para-a-maturacao-de-queijos-em-araxa/

Pereira, B. P., Vieira, T. R., Valent, J. Z., Bruzza, A., Wagner, S. A., Pinto, A. T., \& Schmidt, V. (2014). Implicações do processo produtivo na qualidade do queijo artesanal Serrano. Revista Eletrônica em Gestão, Educação e Tecnologia Ambiental, 18, 116126. doi: $10.5902 / 2236117013183$

Pereira, M. N., Freire, I. S. F., Escatolin, L. C., Silva, J. R., \& Caon, S. (2018). Qualidade do Queijo Artesanal Serrano catarinense quanto à contagem fúngica, aflatoxina M1 e sujidades. Pubvet, 12(7), 1-8. doi: 10.22256/pubvet.v12n7a121.1-8

Picinin, L. C. A. (2010). Quantidade e qualidade da água na produção de bovinos de leite. Anais do Simpósio de Produção Animal e Recursos Hídricos, Concórdia, SC, Brasil.

Pontarolo, G. H. (2014). Qualidade e inocuidade do Queijo Artesanal Serrano, do leite e da água utilizados na sua produção, em Santa Catarina. Dissertação de mestrado, Universidade do Estado de Santa Catarina, Lages, SC, Brasil. Recuperado de http://www.cav.udesc.br/arquivos/id_submenu/757 / dissertacao_mca_giane_helenita_pontarolo.pdf

Portaria de Consolidação $n .5$ de 28 de setembro de 2017, Anexo XX. Consolidação das normas sobre as ações e os serviços do Sistema Único de Saúde. 
Recuperado de https://portalarquivos2. saude. gov. br/images/pdf/2018/marco/29/PRC-5-Portaria-deConsolida----o-n---5--de-28-de-setembro-de-2017. pdf

Portaria n. 146, de 07 de março de 1996. Aprova os Regulamentos Técnicos de Identidade e Qualidade dos Produtos Lácteos. Recuperado de http://www. http://extranet.agricultura.gov.br

Sales, G. A. (2015). Caracterização microbiológica e físico-química de queijo Minas artesanal da microrregião de Araxá-MG durante a maturação em diferentes épocas do ano. Dissertação de mestrado, Universidade Federal de Minas Gerais, Belo Horizonte, MG, Brasil. Recuperado de http:// www.bibliotecadigital.ufmg.br/dspace/handle/1843/ SMOC-A4MHTZ

Sequetto, P. L., Antunes, A. S., Nunes, A. S., Alcantara, L. K. S., Rezende, M. A. R., Pinto, M. A. O., Fontes, G. G. (2017). Avaliação da qualidade microbiológica de leite cru refrigerado obtido de propriedades rurais da zona da mata mineira. Revista Brasileira de Agropecuária Sustentável, 7(1), 42-50. doi: 10.21206/rbas.v7i1.388
Silva, N., Junqueira, V. C. A., Silveira, N. F. A., Taniwaki, M. H., Santos, R. F. S., \& Gomes, R. A. R. (2010). Manual de métodos de análise microbiológica de alimento e água. São Paulo, SP: Varela.

Taffarel, L. E., Costa, P. B., Oliveira, N. T. E., Braga, G. C., \& Zonin, W. J. (2013). Contagem bacteriana total do leite em diferentes sistemas de ordenha e de resfriamento. Arquivos do Instituto Biológico, 80(1), 7-11. doi: 10.1590/S1808-16572013000100002

Vernozy-Rozand, C., Mazuy-Cruchaudet, C., Bravai, C., \& Richard, Y. (2004). Comparison of three immunological methods for detecting staphylococcal enterotoxins from food. Letters in Applied Microbiology, 39(6), 490-494. doi: 10.1111/j.1472765X.2004.01602.X

Wolupeck, H. L., Raska, H. R., Rossa, L. S., Biasi, R., \& Macedo, R. E. F. (2012). Evolução da qualidade microbiológica de queijo Minas frescal comercializado em Curitiba (PR) no intervalo de 10 anos (1999 e 2009). Revista Acadêmica Ciências Agrárias e Ambientais, 10(3), 243-252. doi: 10.7213/ academica. 7707 
